\section{Bruce Mau,}

\section{Head for Heights}

Más que una biografía, Bruce Mau merece una bitácora. Comienza su travesía cuando deja tempranamente el Ontario College of Art and Design para trabajar en el estudio de diseño Fifty Fingers, situado en Toronto. Su siguiente parada, dos años después, fue en Pentagram, al otro lado del Atlántico, en Inglaterra (Smith, 2016; de Monchaux, 2007). En el Reino Unido de la década de los ochenta - post guerra de las Malvinas/Falkland y liderado por Margaret Thatcher-fue «realmente introducido a la vida política de la forma (...) [y allí fue donde aprendió] cómo diseño y cultura se trenzan alrededor del lenguaje, la equidad y la sociedad» (de Monchaux, 2007). Volvió de Europa consciente del impacto social del diseño y de su potencia para transformar el mundo: como él mismo declara, desde entonces cambiar el mundo se ha convertido en su proyecto. Consecuentemente, asume el desafío de diseñar no solo para contener y desplegar correctamente una determinada información, sino para producir modelos que materialicen y aumenten aquello que contienen. Con estos objetivos en mente, ha dedicado más de tres décadas a articular actores, regiones, disciplinas y saberes diversos. Desde entonces, Bruce Mau no se ha detenido: Public Good Design and Communications, Bruce Mau Design, Massive Change
Network, Institute Without Boundaries, Freeman, Zone Books, I.D. Magazine, Incomplete Manifesto for Growth, Eye, $S, M$ $L, X L$, Life Style, Massive Change, Profesor Asociado Cullinan en la Escuela de Arquitectura de la Universidad Rice, guía de tesis en la Universidad de Toronto - Facultad de Arquitectura, Paisajismo y Diseño-, artista residente en el Californi Institute of the Arts, académico visitante en el Getty Research Institute de Los Angeles, miembro del Comité Consultivo Internacional del Wexner Center en Columbus, miembro honorario del Ontario College of Art \& Design, miembro de la Real Academia Canadiense de Bellas Artes...

Premio Chrysler por Innovación en Diseño, Toronto Arts Award en Arquitectura y Diseño, Doctor Honorario en Letras de la Universidad Emily Carr de Arte y Diseño, Miembro Emérito del Design Futures Council, Miembro Distinguido del Instituto de Diseño Segal de la Northwestern University, Premio a la Excelencia en Diseño del Museo de Arte de Filadelfia y Premio Nacional Design Mind del Cooper Hewitt.

Sin embargo, al conversar con Bruce Mau, lo realmente inquietante es cómo naturaliza las escalas y las redes globales que habita e incorpora en su proyecto Massive Change. Tal como hicieran los Mohawk, recordados por su trabajo diario sobre las vigas de acero de los primeros rascacielos, este diseñador de ecologías nos lleva por un recorrido que desafía el vértigo. La familiaridad de su tono contrasta con los flujos glocales a los que se refiere durante su narración, en la que el protagonismo se alterna entre paises, un encuentro con estudiantes secundarios, el planeta, la tecnología del automóvil, tres décadas de trabajo y su sobrina.

More than a biography, Bruce Mau deserves a log. He begins his journey when he leaves the Ontario College of Art and Design prematurely to work in the design studio Fifty Fingers, located in Toronto. His next stop, two years later, is Pentagram, at the other side of the Atlantic, in England (Smith, 2016; de Monchaux, 2007). In the United Kingdom of the 1980's - postMalvinas/Falklands war and led by Margaret Thatcher -he was "actually introduced to the political life of the form (...) [and there he leared] how design and culture intertwine around language, equality and society" (de Monchaux, 2007). He returned from Europe aware of the social impact of design and of its power to transform the world: as he declares, from then on changing the world has become his project. Consequently, he assumes the challenge of designing not only to correctly contain and unfold a given information, but to produce models that materialize and expand all that they contain. With these goals in mind, he has dedicated over three decades to articulate actors, regions, disciplines and diverse knowledges.

Since then, Bruce Mau hasn't stopped: Public Good Design and Communications, Bruce Mau Design, Massive Change Network, Institute Without Boundaries, Freeman, Zone Books, I.D. Magazine, Incomplete Manifesto for Growth, Eye, S, M, L, XL, Life Style, Massive Change, Associate Cullinan Professor at Rice University School of Architecture, Thesis Advisor at the University of Toronto - Faculty of Architecture, Landscape \& Design - Artist in Residence at California Institute of the Arts, Visiting Scholar at the Getty Research Institute in Los Angeles, Member of the International Advisory Committee of the Wexner Center in Columbus, Honorary Fellow of the Ontario College of Art \& Design, Member of the Royal Canadian Academy of Arts. Chrysler Award for Design Innovation, Toronto Arts Award for Architecture and Design, Honorary Doctor of Letters from the Emily Carr University of Art and Design in Vancouver, Senior Fellow of the Design Futures Council, Distinguished Fellow of the Segal Design Institute at Northwestern University, Philadelphia Museum of Art Design Excellence Award, Cooper Hewitt National Design Award for Design Mind

However, when talking with Bruce Mau, what's really disturbing is how he naturalises the scales and global networks he inhabits and incorporates into his Massive Change project. Like the Mohawk, remembered for their daily work over the stee beams of the first skyscrapers, this designer of ecologies takes us for a vertigo-defying tour. The familiarity of his tone is contrasted by the glocal flow he refers to in his account, in which take turns the protagonism of countries, meetings with high school students, the planet, automobile technology, three decades of work and his niece. 
Al visitar suffascinante carrera profesional,

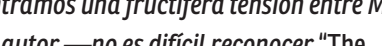
como autor - no es dificil reconocere "The Mau'sway" - y Mau comocoautor - Defo que cualquiera litiere," Apoyate sobre los hombros de otro", yespecialmente el "17.

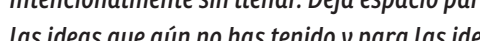
de los demás " (Mau, 1998). La incompletitud constituye un lugar para el juego, un espacio vacio y abierto para interactuar y especular, fascinante como el que se encuentra tatuado en La espalda del Hombre lustrado de Ray Bradbury cundo usted desarrolla conceptos como "crecimiento" o " cambio masivo", adopta especie de estrategia hermenéutica: no describe el concepto mismo, sino sus múltiples contextos, los asuntos circundantes, los principales agentes y sus huellas. usted articula tácticas tener en cuenta mientras experimentuat para crecimiento, o para animar a las personas a unirse al cambio masivo Pero so ocupa de mantener la discusion abierta, evitando las conclusiones deffinitivas. PPodría comentar La relevancia de lo indefnidido para su proyeccio

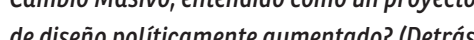
de esta pregunta están las ideas del flósofo coreano Byung-Chul Han (2014, 2015) contra transparencia absoluta.

Mi proyecto es realm Siempre mantengo la tensión entre habitar sistema abierto y la entrega de un producto. Pero ya que vivo en un mundo donde tienes que conctelar proyetelos, inv verdadero proyetio es de trabajndo Mi modo de trabajo es a muy pero a muy largo plazo. Todavía estoy trabajando en proyectos que empecé hace 15,20030 años, pero que aú no logro anidar. Mantengo la práctica de segur adelante con estos proyectos a la vista: sé que con tiempo las cosas encuentran su lugar. A veces es demasiado pronto, demasiado temprano para que el mundo se interesese por estas ideas o

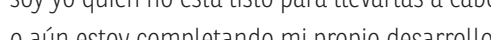
articulando mi propio entorno ta incompletich de estos conceptos, "crecimiento" y "cambio masivo", es una condición muy poderosa para mí, ya que debemos desarrollar sistemas abiertos que permitan e inviten a la gente a entrar en la red. Pensar desde el diseño implica concebir estos asuntos como ecologías, no como objettos. El diseño como ecología es un sistema complejo en red que abre espacio para otros, incorporando
When revisititing your fascinating professional
career, we find a productive tension between Ma as author -it's not hard to recognize 'The Mau's Way' - and Mau as co-author - "Let anyone lea "stand on the shoulders of others", and especially

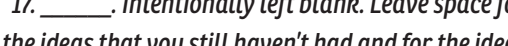
of others" Mau, 1998) Incompleteness is a placefor play, an empty, open space to interact and speculd in, as fascinating as the one tattooed in the back of Ray Bradbury's Illustrated Man (1951/2012). Consequent with this incompleteness, when you develo concepts like Growti' or Massive Change do not describe the concept itself but its multiple contexts, the surrounding issues, the main agent and their traces. You articulate tactics and considerations about our present world to tale Into consideration while we experiment Growth, or to encourage people tojoin the Massive Chang

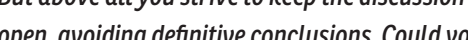

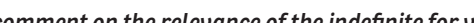
Massive Change Project (Mau, 2005), understood as a politically augmented design project? (Behind this question lie the ideas of Korean phillosopher Byung-Chul Han (2014, 2015) against absollue transparency.

My project is really a kind of incomplete, undefined and open engagement. I lalways have a tension

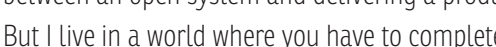
projects. My real project is investment t am essentially working on the same thing I was 35 years ago. I have a very long-term way of working lam still working on projects I started 15, 20 or 30 years ago, but that I cannot seem to find a home for. Ikind of sustain this practice and keep going know over time things find their home. Sometim its too soon, t's too early for the world to be intersted in then, or havent yet completed my

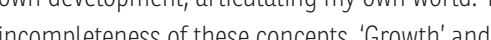
'Massive Change', is a very powerful condition for me so we should develop open systems that all people into the network

For that, the very thinking of design implies conceiving these issues as an ecolooyy not as objects. Design as an ecology is a complex netwo system that allows space for others, incorporatin the power of collaboration, the power of people

(n)

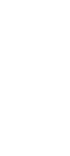

(n)

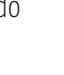

el poder de la colaboración, el poder de las personas que entran a dicho sistema. Es tuve una conversación con mis sobrina ya que ella tenía que hacer un trabajo para su clase sobre el éxito. Lo que le dije es que, probablemente, la principal característica, lo que une a quienes lienen exito, es que no concluyen su tarea cuando personas consideran un fracasso, desde mi punto de vista es recién un comienzo, una muestra de que es hora de seguir andando. El movimiento constante es complemento de lo incompleto, y como tal es muy importante.

La incompletitud está asociada al reemplazo de los problemas singulares por los sistemas complejos como contextos para el desarrollo de los proyectos de diseño. La forma clásica separarallo det contar et problema, describirilo y singulary desarrollar una solución también singular- nos permite un cierto grado de certidumbre de que, dentro del marco definido por nosotros, podremos resolver dicho problema singular. Pero creo que necesitamos una visión diferente respecto del problema. Tenemos que entender el problema como una ecología, verlo incrustado en un sistema compleso de relaciones. Debemos reconocer que el todal a ecología aue lo contano, sino enraizado en en la ecología del mundo. El brief no debe ya narrar solamente la relación uno-a-uno entre problema y solución. Una vez que te desprendes del problema singular ya no solo tienes que alseñar un automovil. Desde la mirada tradicional del diseño, un automóvil es solo un automóvil. Hoy el problema es la ecología global del del coche pero a quad as ellzay velocidad que encaje y se sostenga en nuestro fuevaromanera

Ecología es una palabra emocionante una ided que en nuestra escuela hemos estado trabajando. supongo quees un concepto constitutivo de nuestro tiempo. El s sociólogo Fernando Domínguez Rubio (2016), quien vivey ytrabaja en San Diego, California, plantea que una ecologia es tanto un sistema abierto, en el que puedes entrary y participar, como tambien nno cerrado, con un Limite reconocibles ecologia que ind rob. Massive Change esuna iqueda alguien fuera? :Quét tipo de límites presenta Massive Change?

Intentamos ser lo más abiertos posible. Desde que la manera más completa posible, y preguntarme entering the system. II's an interessting thing
the one you pick up. Some time ago I had a conversation with my niece, because she had to do a review for her class about success. What I said is that probably the main characteristic, the one common to all who are successful, is that circling is not ending, when other people will Ithink it's sust a starting and it's time a talunge going Constant movement sa sup to keep incomplete, and it's a very important one.

Incompleteness is associated with the shift from the

singular to the complex system as the reat poitt

of design The classial idea of desion - clarifing a problem, making a problem discrete and cutting problem and develop a singular solution- allows us a degree of certainty that, within the framew defined by us, we will succeed in solving this view about the proble

We need to understand the problem as an ecology, see it embedded in a complex system of not packaged, but rooted in the complex ecology that contains it and, in sum, in the ecology

of the world. The brief should no longer $j$ ws

narrate the one-to-one relation between problem and solution. Once you get rid of the singular problem you have not only to design a car. From a traditional perspective on design, a car is just a car. Today the problem is the global ecology of the

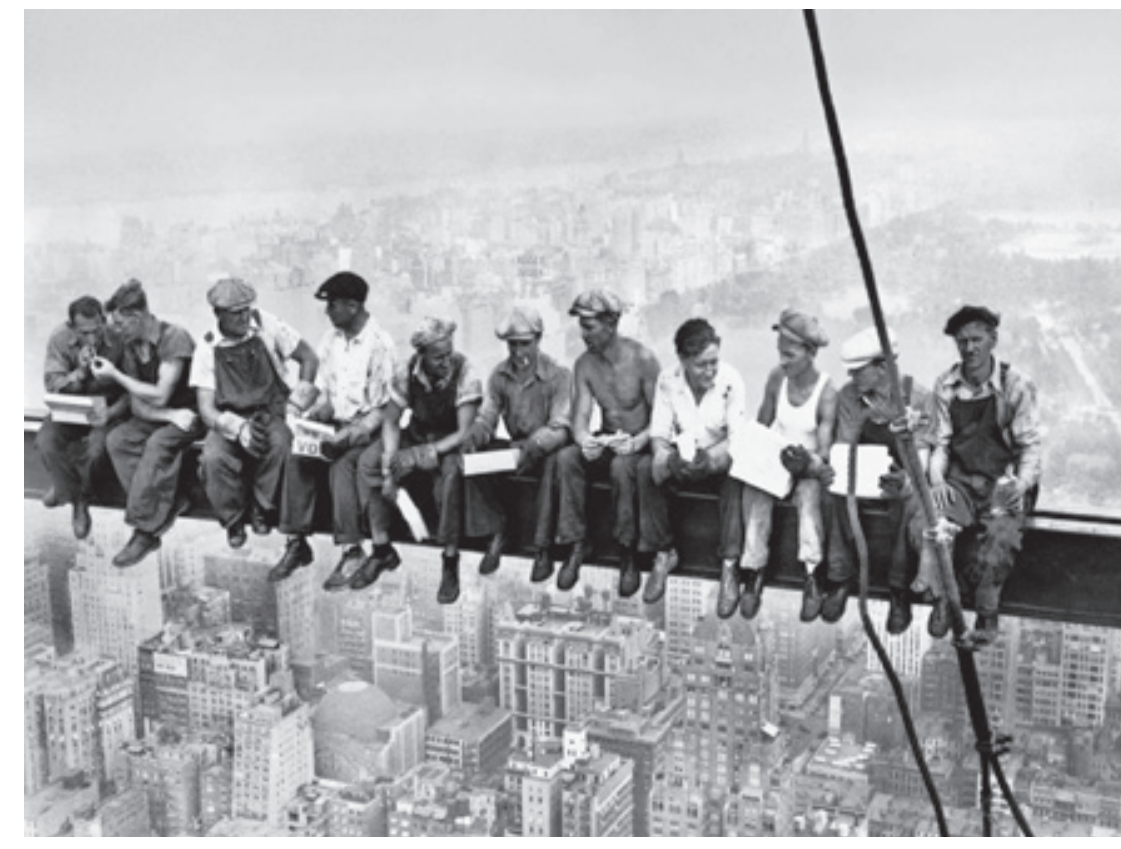

29 de septiembrede
1932: :rabaiadoresestela construcción almuerzan
sobre una viga de acero a 250 metros del suelo durantela

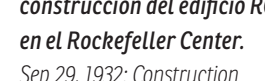

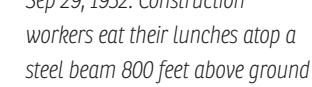
at the building site of the RCA
Building in Rockefeller Center Fotograffial Photograph:
Atribuida a Atribitued to Charles C. Ebets.
Fuentel source: New Yorl car. We want alt the beauty and the speed of the car, but we want tinn a new way that is sustainable

El diseño como ecología es un sistema complejo en red que abre espacio para otros, incorporando el poder de la colaboración, el poder de las personas que entran a dicho sistema.

Design as an ecology is a complex network system that allows space for others, incorporating the power of collaboration, the power of people entering the system.

Ecology is an exciting word, an idea that we' ve bee working in... I Supposes that it's part to for times.
Sociologist Fernando Dominguez Rubio (2016). who lives and works in San Diego, California, suggests that an ecology is both an open system, one in which you can enter and participate, and and certin rules of the geme Massioundary an ecology that certainly invites you in. But, does anybody remain outside? What kind of boundaries does Massive Change have?

We try to be as open as possible. When I am starting the work, my goal is not to have those limits, to really try and explore the complexity the fullest possible way, and ask myself, without 
sin prejuicios cuál es el potencial de aquello a que me enfrento. Estoy convencido que de allí proviene desarrollar una metoodología para entender una ecología y rediseñarla, también estás diseñando su economía. Y ass puedes realmente visualizar, ver las economías tangenciales a la ecología tratada, as que pladen ser claves para adelata

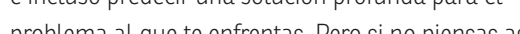
pierdes el sentido de las cosas, te arriesgas a las consideraciones impertinentes.

Di una conferencia en el Museo Cooper Hewitt me hice la siguterte denominador de todos los diseñadorese incluidos en la colección? Creo que el denominador

común es "cuidar". Si analizas su quehacer, los diseñadores están obsesionados con el usuar individual, con la experiencia del usuario Individual. Cualquiera que sea el producto, sea cual sea, no de destes recter es una idea fundamentalmente polficica Porcue - nos preccupamos porgue cuidamos del ciudad y. por extensión, cuidamos de su comunidad, cono quiera que definamos esta útima idea - puede Ser una red global de usuarios o una comunidad Local, acotadda a un Lugar-. Pero, a fin de cuentas,
si cuidamos a los ciudadanos, tenemos que cuidar si cuidamos a los ciuddadanos, tenemos que cuidar
su contexto y, por extensión, debemos comprender su contextoy, por extension, debemós comprender
con nuestra acción su ecologiá. Asi, esta impronta constitutiva del diseño, que es la obsesión por la experiencia del usuario individual, se convierte en ecología, una comunidad y una persona exitosas.

Justamente, en la Escuela de Diseño UC, estamosen proceso de transformar nuestras consideraciones metodologgicas demanera de mover el foco deste sewdro hacia la ecologifa que lo comprende, que Es un gran reto porque tanto las ciencias sociales comolas natu indivisible como unidad final de análisis. ER problema que afrontamos es cómo desarroll una metodologia de diseño que efectivamente considere como figura principal a la ecología

Es un problema muy desafante, porque lo obvio en nuestra caltura de diseno es totatmente lo descritos problemas descritos crando de hecho lo gue realmente se requiere es incrustar ese problema en la compleja ecología social y fís desde la que emerge.

any prejudice, what's the potential of what I'm (reative impact comes from Besides if tyou really develop a methodology to understand the ecology, and re-design it, you're also designing the economy. And, this way you can really render, you can really see the tangential economies, which providing a rofor you're dealing with But if jou do not think in that way, you're out of sense with things, you risk making considerations that are not pertinent I gave a lecture at the Cooper Hewitt Museum and lasked myelf about what the common denominator was of all the designers they collected. It think the common denominator 'caring'. If you analyse what they do, designers are obsessed with the individual user, with the experience of the individual user. Whatever the product is, be it a car, an interface, or identity, Because we care we care about the citizen and extension, we care about the community and, by we define it I t may be a community of users that is global, it could be a local community, in a local place. But, in the end, if we care about the citizens, we must care about their context and, by extension, we must understand its ecology with our actions. So, this basic impulse of design, which is the obsession with the Individual user

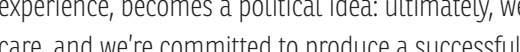
ecology, community and person.

process of transforming our methodological

individual to the ecology that contains him, as our

unit of observation and intervention. It's a great challenge, becausebon hesocial as well as the

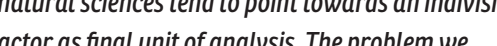

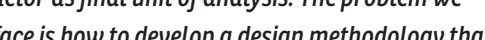
effectively considers the ecology that its users inhabit as its main figure.

It's a very challenging problem, because the hatural thing in our culture of design is really the opposite, as I've mentioned: to create discretete objects, and discrete problems, when in act you really want that problem embedded the complex soctad and physical acology

Así, esta impronta constitutiva del diseño, que es la obsesión por la experiencia del usuario individual, se convierte en una idea política: en última instancia, cuidamos y estamos comprometidos en la producción de una ecología, una comunidad y una persona exitosas.

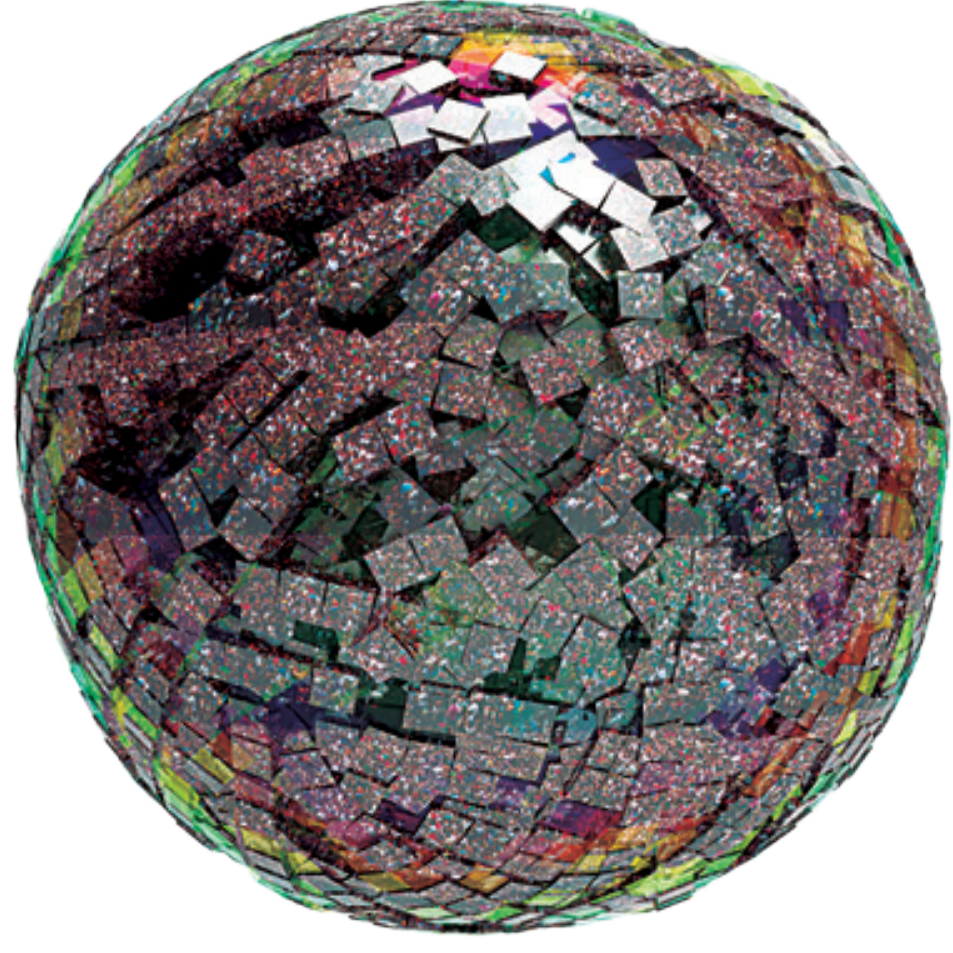

Entender, como usted propone-inspirado en Amold Toynbee-,el lisenio del Mundo como

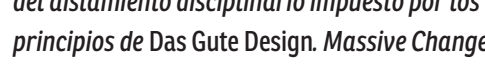
promueve un salto desde un espacio cerrado una red globalizada de eventosy situciones interrelacionados, o como lo lamaría Bruno Latour (1994), una ecología planetaria sociotecnica. Pero silitieralmente seguimose salto que usted sugiere, pasamos sobre la escala de 1 ds

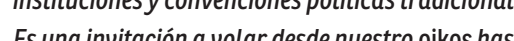
el cosmos Esel Diseño del Mundeellamado a una acción glocal que desprecia la escala de la polis como espacio de los rituales politicos? ? 0, contrario, nos invita a re-articulary yre-vitalizar lintes del (iego) stado-Nacion? No creo que esa sea la manera de pensar. Creo que el Estado-Nación esta ahi, como una mundo, Los Estados Levanto un cerco. En pared en el caso de Estado Unidos- pero debemos pensar independientemente de la independientes de la pared, para luego mira la pared o la valla, describirla y construir un sentido, asumiendo nuestra posición respecto de la pared, pero no pensando a partir de ella. Necesitamos, más que nunca, que los diseñadores, que estan interviniendo en tod Las escalas imagnnables, piensen y tomen Tog be ajo Toynbee djo que el bienestar de toda la Bueno, cuando recién hicimos Massive Chan fui a una escuela en Vancouver a presentar et proyecto a sus estudiantes. Durante las preg después de la exposición, un grupo de estudiantes secundarios nos dijo: «no están pensando de manera suficientemente grande». Yo respondí diciendo «bueno, es toda la humanidda, Toyntee habló de toda la humaniddad». Esa era la idea

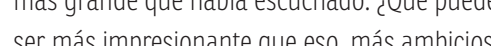
gue eso? los estudintes resond de toda la humanidad incluyendo toda forma vida, ese es nuestro proyectoy, Cuando escuche eso, pensé iquiénes son estos niños? : Quée vision más increíble! : Tenían toda la razón!! De repente imaginé el bienestar de toda forma de vida con un objetivo práctico. El concepto de "toda la humanidad correspondia a una era anterior a nuestro tiempo, una era donde los seres humanos estabamos aribay d resto ce ta naturaleza noción de que estamos separ del abjetivo práctico, saca a los alisentadores nuestras relaciones polificas considerando los
Understanding as you propose -inspired by Anold Toynbee-, the Design of the World as a disciplinary isolation imposed by the principles of from a space enclosed by technical and formal it, a socio-technical planetary ecology (1994). Bu If we follow literally the leap that you suggest, we exceed the scale of tradititional institutions and political conventions. It's an invitataion to jump from the call for a gocas action is e Design of the Worla of the polis as space for political rituals 20 r on the contrary it invites us to rearticulate and revitalize our political relations considering the limits of the (old) Nation-State? are but we must think independent of the fence dependent of the wall, and then look at the wal describe it and make sense of it, assuming our from it. More than ever, we need designers, who re working at all imaginable scales to think and take action independently of the wall.

Toynbee said that the welfare of all mankind . to a High School in Vancouver to present the project to the students. During the questions, after the takk, a group of high school students said to us: "youte not thinking big enough" and about all mankind" That was the biggestidea I ever heard. What can be more impressive than hat, more ambitious than that? And the students answered: "take care of all mankind including all life. That's our project". When I heard that, thought: who are these kids? Such an incredible insight! They were absolutely right! I suddenly imagined the welfire of alt life forms as a practicat objetive. The concepto 'all humanily' we were above and the rest of the nature was below. And we were separated. And in fact that concept of being separated is over.

So, this basic impulse of design which is the obsession with

the individual user experience, Das Gute Design. Massive Change promotes a shif events and situations as Bruno Latour would call

becomes a political idea: ultimately, we care, and we're committed to 
En realidad, somos parte de la vida, somos vida,

y esto es verdaderamente crucial.

We're actually part of life, we are life and this is really critical.

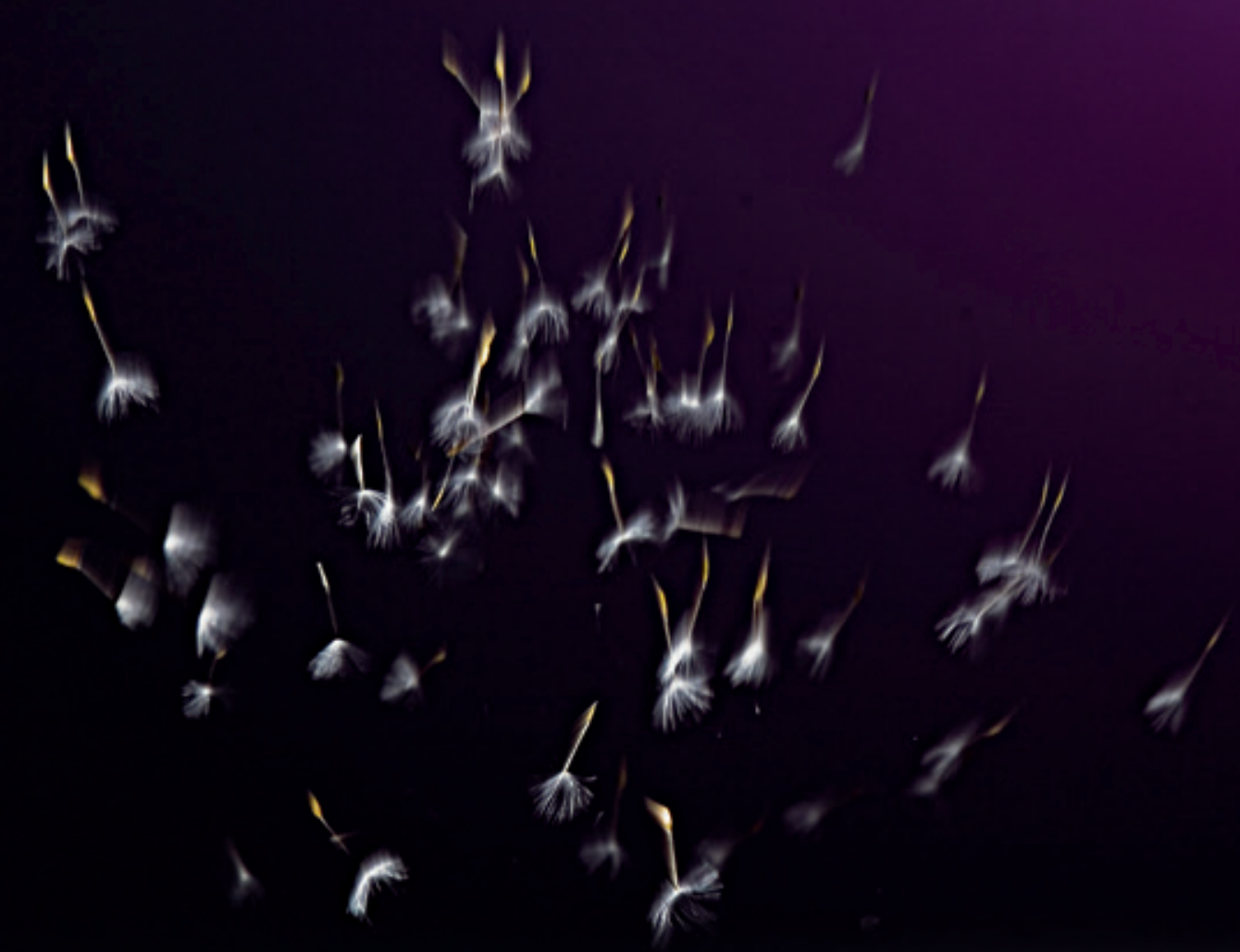

3

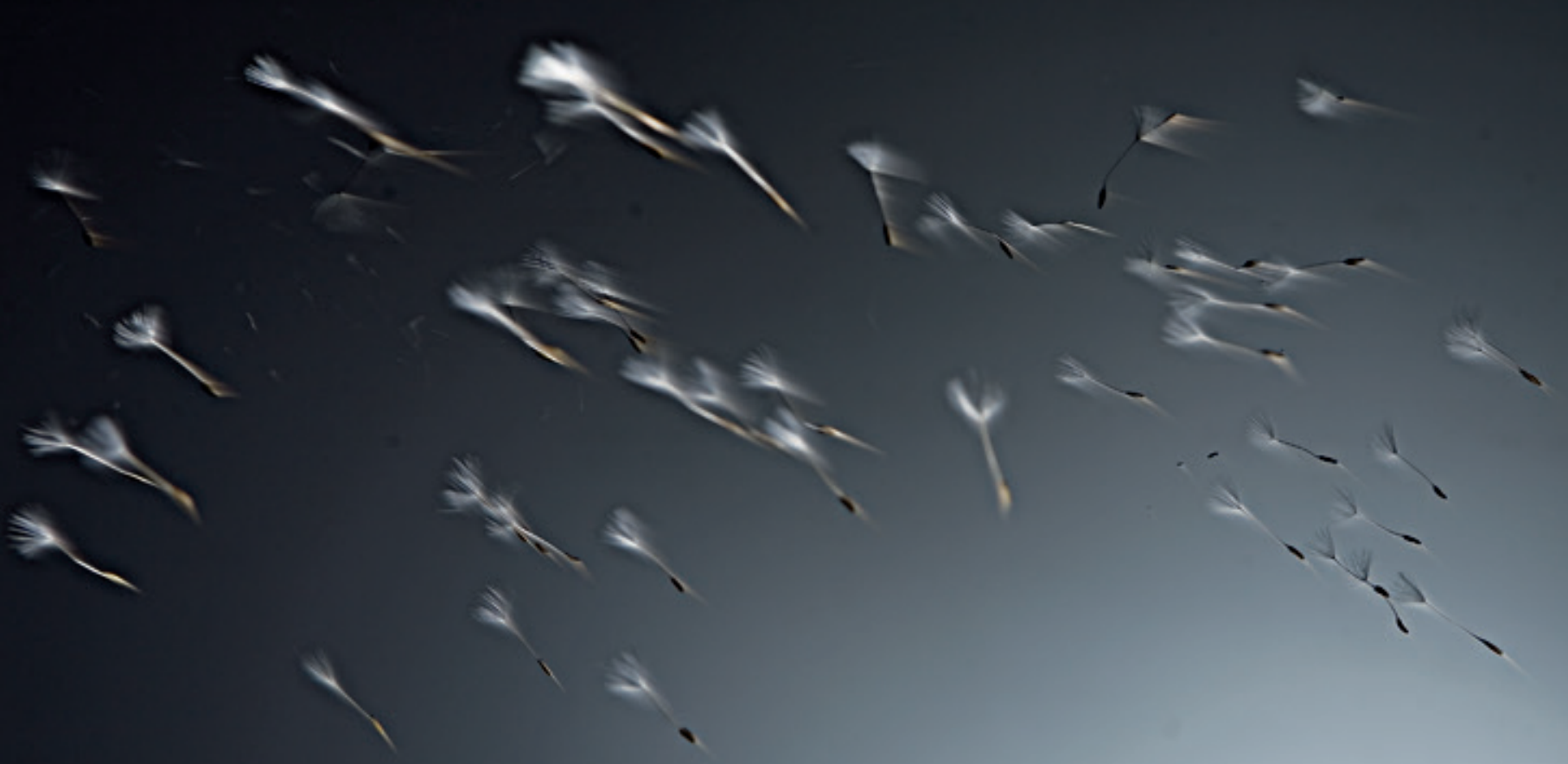

En realidad, somos parte de la vida, somos vida, $y$ transcurridos desde entonces han sido realmente Importantes para este objetivo practico, ya que esta

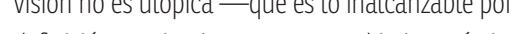
definicion-, smojustamente un ojeletivo practico,

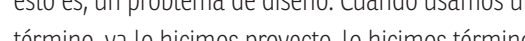
de diseño Si entendemos una ralididad ecolócica. e incerporamos la ciencia de la ecologí tenemos que ver y trabajar de esa manera. La ecología no tiene naciones, no tiene fronteras, esa es la forma en que tenemos que pensar. Y ese concepto es uno de los principios que desarrollamos en Massive Change: no estamos separados de, ni por sobre naturaleza. Eso nos cambia fundamentiamente. Tuvimos el privilegio de trabajar con E. O. Wilson a la selva con Wilisony realmente, esa fue una experiencia aue cambió nuestra, vida Nos explío que solo hay una cosa en el planetay y eso es ta vida. Usando una exxresión maravillose, nos explico que «la vida es roca rápida y la roca es vidda lenta» Tenemos que motivar a nuestros ciudadanos movilizarlos de nuevo, y también a nosotros mismos, en todos los niveles y escalas. Requerimos de una forma de pensar que no privilegie una

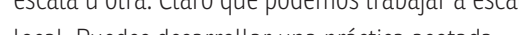

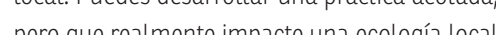
pero que reamente mpacte rna ecologra local. conexions a a scalala planetaria.

Cuando yo era joven, tenía una imagen en partículas que rodeaba todo el mundo, y en delgada capa de finas partículas, las partículas eran las personas que yo estaba buscando. Ellos tambiein me buscaban, pero aún no to sabian. Y la unica manera en que pocia acercarme a ellos erd emitlendo una senal pura en ess capa.s me encontrarín Lo gue tenía para ofrecer era tan fráqil, que tenía que ponerlo en un mensaje muy claro y por mucho tiempo para encontrarlos. Y tuve la gran suerte de encontrar a quienes encontre. Encontre uno en Canada, dos en Nueva York, uno en Paris... asi encontré a la gente que estaba buscando. El concepto que subyace a esta senal es pensar $y$ trabodar a escalas globales, pero tlevanoo esa misma melocologra a escala local. Esta Puedes tom ta meston mismo a tu fail a a a comunidad A su vez puedes comprender cada una de esas escalas como algo fisico y localizado, o en su dimension informacionaly g global. Ese es el sistema nervioso de Massive Change.
We're actually part of life, we are life, and this is fifty years passed since then ave been really important for this practical objective, because this is not a utopian vision -that is unreachable by definition-, but a parteal objective, that is, a design problem. And méve mase ita des re made car project, fe understand an cocogat resty cology, we have to and work in that way Ecology doesn't have nations, doesn't have borders. It's the way we 政 principles we developed in Massive Change: we rem or above nalue. That

Norking with E. O. Wilson

the jungle with Witson and it readly was a tife changing experience. He explanined that there is ande thing on the plane, and hat is tre. Using fast rock, and rock is slow life".

We need to galvanize or mobilize citizens,

of thinking that desn't privalese. one sead a way another. Of course, we can work at a local scale. You can have a local practice and really shape a local ecology. But we can also go beyond that and find connections at a global scale.

When I was a young man I had an image in $m y$ mind that there was a thin layer of particles that surrounded the whole world, and in that thin

layer, the particles were the people I was looking for. And they were also looking for me, but they diant know yet. And the only way that could reach them, was pulting a pure signatinto that sanal they wold neve find me It was so veak what I had to offer, that I had to put out a very clear message, for a long time, to find them And was very lucky to find what I found. I met one Canada, two in New York, one in Paris... so fund the people I was looking for

The concept behind this signal is to think and work at global scales, but taking that very same methodology to a local one. This way of thinking is very pragmatic. You can take a methodology and apply it to yoursell, to your youly and our commanty. At he same time, you can understand each one orthese scales informational and global dimension That is the nervous system of Massive Change. 


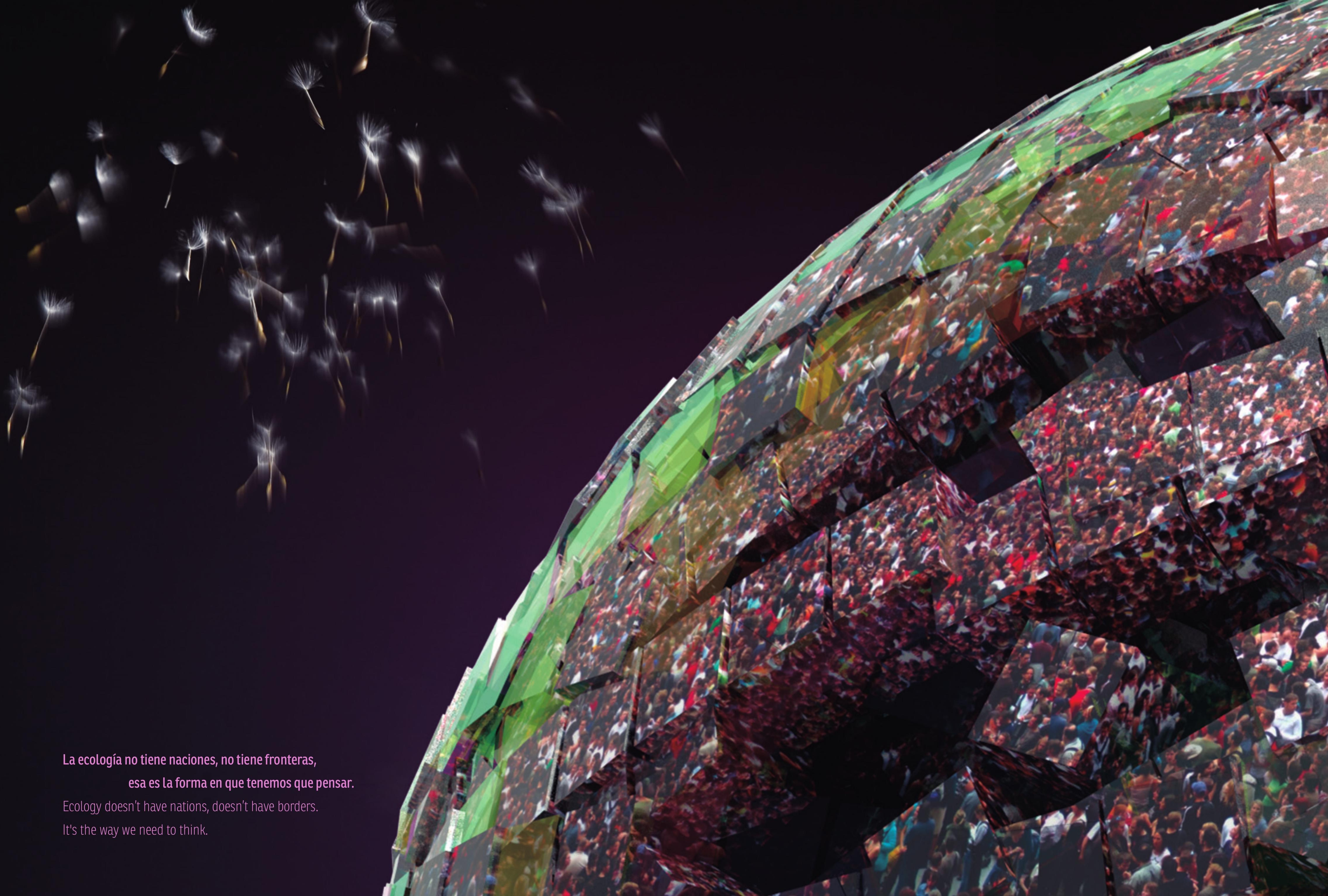


Permitame citar una de sus reffexiones sobreel diseño: :Entonces, cicomo convenceemos a más que es cambiar la forma en que viven? Pensem en la zanahoria, no en el garrote. Seducción, no sacrificio." "SIl", no" "no!" Debemos reeimaginar tod ala gente experimentar belleza alegría amor placer y deleitex) (como se citó en Berger 2010) describir casosos seleccionados y exitosos, su menso sincroniza con el «Sir de obama. En su inteligente optimismo resuena la máxima de Arnold Toynbee, - Els siglo $x$ s sera recordado principalmente por conffictos políticos o invenciones técnicas sin como una época en la que la socieddd humana atrevióa pensar en el bienestar de toda la especie humana como un objetivo prácticon, (1958/2015). Ahora, esta alentadora manera de promover la acción politica tiende a omitit los esfuerzos infructuosos. Las comaniladese que sin exito han para (re) diseñar el mundo Siqueremos crecer puede ser vital conocer y empatizar con algunos Massive Failures ejemplares, constituidos por sujetosy comunidades recalcitrantes. ¿Fueron la Segunda Repubblica Espaniola oel gobierno d Salvador Allende solo proyectos descarriados, heroicas? O, quizás, ciertos aspectos de estos poéticos poeticos prototom
para deliberar.

Un par de reflexiones sobre esto. Primero, el diseño debe integrar el fracaso. Un montón de negocios y nichos culturales sostienen que el fracaso debe estar fuera de las opciones posibles, y ass creen mantener el fracaso a del pensamiento de disenio integra el fracaso dentro del sistema. Su protocoto trata de hacer posible, lo que finalmente permite Lograr lo que te propones. La idea de red es clave para comprender la distribución del fracaso y del éxito. En otras palabras, el método de diseño es un proceso de liderazgo para gestionar el fracaso y su distribución. El diseño no intenta eliminar el fracaso, sino integrar las fallas com parte del proceso.

Presenté una charla sobre lo que otras personas llaman fracaso. El fracaso es simplemente una

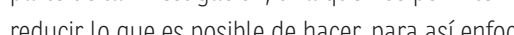
la indagación hacia un objetivo central Un fracesso permite decir «bien eso no funciona, sabemos que no funciona, y no solo creemos aue no funciona Y saber que no funciona es un asunto realmente crítico. La mayoría de las organizaciones solo
saben cómo distriburir el êxito, siendo gue ta
Allow me to quote one ofyour reflections on design So how do we convince six-bililion-plus people that changing the way they live is important? Think carrot, not stick. Seduction, not sacrifce.
'Yes!' not 'No!' 'We must treimagine everything we 10. But we must do so in a way that allows people and delight" (as cited in Bi Bergar, 2010). When describing selected successful cases, your mess synchronizes with Obama's' Yes'. In its intelligent optimism resounds Arnold Toynbee's maxim: "The $20^{\mathrm{n}}$ Century will be remembered chiefly, not as an age of political confilicts and technical inventions think of the heolt th of the whole human race as a practical objective" (Toynbee, 1958/2015). Now, this encouraging way of promoting political action tends to omit the fruitless efforts. The communities that have worked hard unsuccessfully can be important references to (re)design the world Is we want to grow, it can be crucial to know Failures, constituted by hard-line eindividuals and communities. Were the Spanish Second Republic or Salvador Allende's government only stray projects, extemporaneous visions of the world heroic mistakes? Or maybe some aspects of thes poetic politic

A couple of thoughts on this. First, design mus integrate falture. A toot of business and cutturst posible options and thin they an teep follogy at a distance. On the contraryy the methodologe of design thinking integrates failure inside the system. It tries to make it happen quickly, ald to make it happen in the smallest possible scale, allowing you to succeed in your plan. The network concept is readly key to distributing failure and success. In other words, the design nethod is the process of leadership to manag

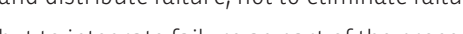
duid ta Lita a talk about what other people catt fal fre hate allows ss to eliminate possibiltites and

focus the research on a main object A failure allows us to say "OK. This doesn't work, we know it doesn't work, we don't thinkit doesst work". And knowing it doesn't work is a really erritical idea. Most organizizations know how key to the future success of every truly great organizaztion. And since our work usually deals doesn't work and why.

ne of the principles of Massive Change is always search for the worst... I mean desian always seeing the world upside down: bad is good, terrible is fantastic. The biggest problems are the biggest opportunities. To do this, we muss begin with fact based optimism. The key idea is fact-based. Not blind up optimism. Fact-based citicat in analysis - is for me a method of exploring failure Teaching this method allows people to coexist to a good extent, with the nevitable failures and errors, despite being told emphatically not to fail.

In a way, what a designer does has a lot of resonance with sport. If you watch a sport, for
instance a game of football a team may suce wwo or three times; they score a goal one time, and many more times they don't. They will fail hundreds of times during the match, even the best players in the world falt most of the echnc, they win by desion, they win by designt aplay and they apply that learning to perform at the highest level. It think that culture of actually finding a way against the odds every time is the very culture of desig.

This constant struggle against failure that you mention implies that we're always or nearly always in conflict with something or somebood, As a form of life, it it ivolves a never ending individuals and communities. This agonistste narrative, complex and endless, is composed of countless tales, successful and otherwise. In so way, those who support from their trenches the production of these non-successful stories also support an agonstic relation with the hegem this agonistic social life is healthy and must be maintained as such? In a way, the celebration of this social agonistic metabolism is contrary to utopias regarding thefuture or the present, like the Habermasian Public Sphere (Haberm 1989), where everything is perfect, eternal and transport agonism to the politics of design

(Mouffe, 2000, 2006). ¿Cree que esta vida social agonistcaes saldabley debe ser mantenida metabolismo social agonistico es contraria a las utopias respecto al futuro o al presente, como 1989), donde todo es perfecto, eterno y armónico Concretamente, cicómo traducir o transportar agonismo a las politicas del lisenina?
Pienso que eso es el núcleo del Design Thinking. Es el nucleo de realidad del diseño. A pesar
de que la imagen del diseño es la perfección, la realidad del diseño es la lucha. Y la lucha perpetuidad. Primero que nada, porque todo éxito es parcial. Cuanno se trata de desatios complejos, ganar nunca es claro; al contrario, si tienes u que hasta los problemas discretos son parte redes complejss ganar en realidad tampocose claro. Incluso lo perfecto, que no es más que instante solo, está saturado de nuevos problem Aun si tenemos éxito, creamos nuevos problemas Necesitamos formas de pensar con diseño en este contexto complejo... aún actuamos como si e producto resultante fuera el objetivo del alsen. Todavía vemos el objeto de autor como nuest principal prod 0 otro de los prino

Otro de los principios inspiradores de Massive Change es "diseñar una plataforma de diseño día legaremos a un estado de éxito deffintivo, pero la realidadd es que diseñamos en ta constante batalla de diseñar el mejor result provisional. Diseñar para la batalla presente de hacer las cosas mejor y mejor. Creo que esa es la realidad de Massive Change. Hay millones de diseñadores trabajando para resolver problemas. y solo algunos pocos casos aportan soluciones definitivas, la mayoría es derrotada por el cambo constante de nuestra ecologra. Cuando Lany

viruela de la faz de a tarera ese fue un qui definitivo. Hoy podemos decir, la viruela ya no existe. Pero muy pocos problemas están su este extremo de claridal

Necesitamos que los diseñadores se sientan

comodos con la incertidumbre que conlleva diseñadores, cuando dije millones de diseñadores realmente me reféro a líderes, porque una de las cosas que nuestra experiencia nos permitto
comprender es aue el diseño es un método de liderazgo que nos da el poder de tener visiones sobre el futurey y la capacidad de eiccutar sistemáticamente esas visiones. Pero la visión la ejecución están siempre separadas. No importa cuán nerfecto sea el plan, es como la experiencia y el recuerdo. La memoria nunca es perfecta respecto de la experiencia, pero nos permite volver a experimentar lo vivido. Ysibien la memoria coincide con lavisión tota,
es en gran medida fallibo.

Las comunidades contra-hegemónicas deben mantener una posicion culturat visibley yactiva
Como cuerpo y conocimiento, conseguidos y
Ithink that's the core of design thinking. It is the core of the reality of design. The image of design And struggle in perpetuity. First of all, because all success is partial. When it comes to complex enallenges, winning is never clear; on the contraly But given that even discrerete problems But given that even discrete problems are part of clear either. Even perfect, which is not more tha a single instant, is saturated with new problems Even if we succeed, we create new problems. We need ways of thinking with design in this complex context... we still act as if the resulting product is he goal of design. We still see the signature object sour main product.

Another principle that inspiries Massive Change is 'design a platform for constant design'. It woulc be nice to think that someday we wic reality is that we desing for of success, but the designing the best provisional outcome Design for the ongoing struggle to make things better and better. Ithink that's the reality of Massive Change. Millions of designers working to solve problems, and only a few cases are definitive solutions, most cases are defeated by the constant change of our ecology. When Larry Britlant and his global team took smallpox our rou can say as of toda smal donntive brear. xists. But very few problems are subject to tha of extreme clarity.

comfortable with the indecisiveness of this new way of working. When Ithink about designers, when I said millions of esigners I really meant leaders, because one of he things we realized in our own process is that esign is a leadership method that gives us the power to envision the future and systematicaly how perfect the plan is, it's like experience and nory. Memory is never perfect in respect to the experience, but it allows us to experience again. vision, the adjustment between them is in a grea measure unsuccessful.

Counterhegemonic communities should sustain avisible and active cultural position. As body and knowledge, achieved and preserved, are kes

El fracaso es simplemente una parte de la investigación, una que nos permite reducir lo que es posible de hacer, para así enfocar la indagación hacia un objetivo central.

Failure is simply part of the research, one that allows us to eliminate possibilities and focus the research on a main object. 
conservados, son criticicos para la sustentabilildad a la diversidal nuestra ecología planetaria. Sostener crucial, y mantener simplemente estos colectivos realmente saludable para nadie.

Cuando usted seenfrenta a problemas extrenadamenteconplesen proyectos deg miemros décíteles sol un mejorfuturo parael pais-pareceimpositio que puede provocar -incluso a corto plazoElcrecimiento politicoy sociall logrado en contextos
dificileseses una buena razón para estar orgulloso de Massive Change. Pero un cambio masivo radical en estose entornos complejos ses imposible. Sup que a veces se siente como Sisifo, y a veces la constante incompletitude es una motivación para seguir creciendo. PPodría reflexionar sobre su
relación con el exito inevitablemente parcial? relación con eléxitti inevita
¿Se sientea veces cansado? ¿Sesientea veces cansado?
Una de mis películas favoritas es Los Increíbles. quiero que el mundo se mantenga a salvols pero en realidad, no me siento asi. Tuve una experiencia muy extraña: me encargaron rediseñar algo que caí en la cuenta de que, princinalmente, estamos des-diseñando y rediseñando cosas que otros han diseñado. Pero, en este caso, tenía que redisenar algo que yo mismo había diseñado unos diez años antesy que necestiada ser rediseñado. Entonces me dicuenta de que, sovre todo cuanno a cargo no era tan inteligente - pesta vez vasosa hacerlo bienl No eran tan buenos, y si hubísen estado allí podríamos haberlo hecho mejor. Esta vez lo haremos bien». Pero cuando te das cuenta de que eras tú el que estaba a cargo la última vez, que hiciste lo mejor que pudiste, comprendes que a pesar del esfuerzo, inevitablemente el mundo cambia. No puedes mantener las cosas estables cuando el mundo entero se transforma. Con esa experiencia me di cuenta de nuestro hybris', te que padecemos de ta a droganci consenso presente. Nos perstadmosy es el más importante. Creemos que el pasado no era tan bueno como el presente mientras proyectamos nuestras posibilidades hacia el futuro. Eso es diseñar realmente en la escala equivocad Necesitamos desarrollar una metodología donde podamos diseñar lo inevitable: ese fue el concep the long-term sustainability of our planetary celogy. Sustaining the diversity and complex hese collectives into the middde, is not really (n)

When you facce extremely complex problems large-scale projects - like the rehabilitation of former members of Colombian drug cartels or supporting Guatemala a te envision and design $a$
better future for the country-it seems simpossibe to foresse the countless impacts and that it may cause-even in the short term. The political and social growth achieved in complex contexts is a good reason to be proud of Massive complexenvironments is impossible Isuppose

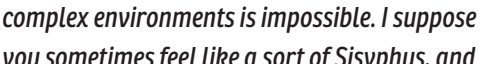
sometimes the constant incompletenessisa motivation to Reep growing. Can you share reflection on how you relate with the inevitably partial success? Doyou sometimesfeel tired? One of my favourite movies is The Incredibles. At one point, Mr. Incredible sayy "Sometimes I just want the world to stay saved!" But actually, I don't feel that way. I had a really strange experience. I was commisssioned to redesign that we're mostly undesigning, and redesigning thigs that other neople designed But in this cose I was redesigning things that I had designed some ten years earlier and that needed to be redesigned. I realized that, mostly when working on redesigning things, we think "the people in in charge weren't that smart... this time we are going to get it right! They werent that good, and

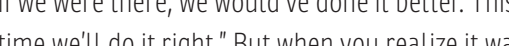

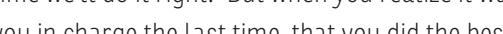
you could, you realize that despite the effort the world inevitably changes. You can't hold things Having that experience, I realize that we suffer from the hubris of the present tense. We. persuade ourselves and agree on the idea that Our present tense is the most important. We believe the past wasn't a g good as the present, I's really designir posstolitties into the future. is toed to destring a he wrong scale. We really an be designed that was the originat con

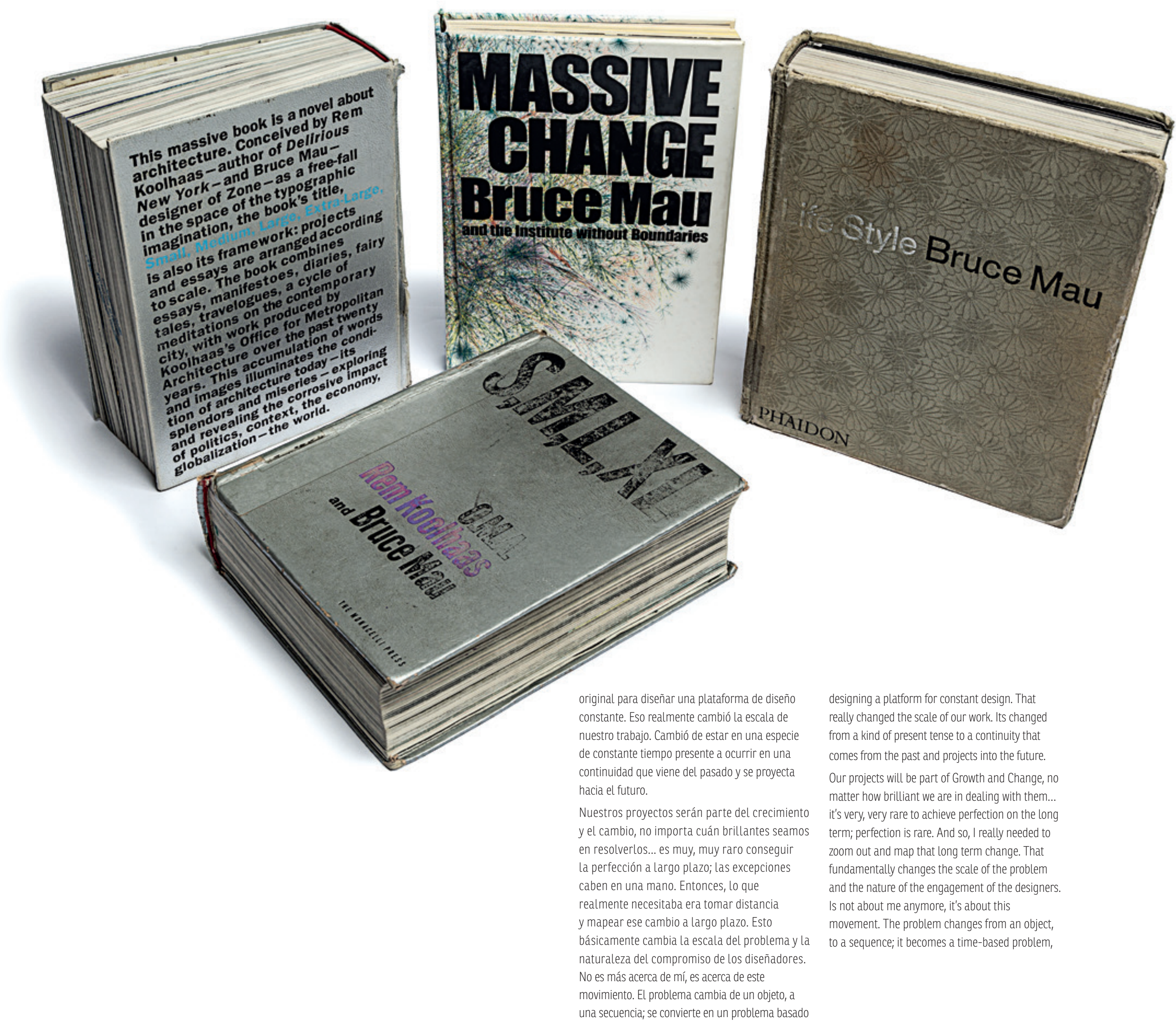

Necesitamos desarrollar una metodología donde podamos diseñar lo inevitable: ese fue el concepto original para diseñar una plataforma de diseño constante. We need to develop a methodology where the inevitable can be designed: that was the original concept for designing a platform for constant design. 
en el tiempo, no es un problema formal. Porque un problema social es un problema que construye
secuencia. De este modo exorcizo a Sisifo, no sient que no progress, que estoy repitiendo un gesto u y otra vez, como si estuviese diseñando la versión

Un patrón subyacente en el conjunto de su trabajo

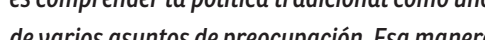
de perar sitún suproyecto del Diseñ del fuera del alcance de las grandes meta-narrativas del siglo XX. Sin embargo, dada la consistencia de su trabajo, parece haber un aglutinante una estructura original einvisible (conceptual, operativa, mistica o emocionall que apoya sus acciones. creee en alguna forma actual de metr a dine movimiento define lo que es absurdo i i mee está surgiendo una nueva meta-narrativa? iSe siente parte de una nueva gran narrativa cree que las meta-narrativas están saliendo para siempre de la escena social?

Si por meta-narrativa hacemos referencia a un movimiento global, yo diría que sí. Creo que hay algo que está sucediendo, el mundo esta despertando. Si observas lo que sucede con el proyecto cientifico, que se está ccelerando velocidad y fuerza inéditas - muchas de sus materias no existrín 20 años atrás-, verás que se están abriendo espacios para diseños que hasta hace poco simplemente no existían.

Cuando hicimos Massive Change vimos este un recipiente con agua en la estufa.... al volver a buscarlo un rato después, había un rí en recipiente. Djumos «Wow! ¿Que es esto?» Luego intentamos mapear en nuestros botes este vér tos, lo llamamos "econoús del dise Habría sido mejor llamarlas "ecologías del diseño" Regiones del mundo, regiones de nuestra cultura humana que han sido diseñadas y rediseñada reinventadas utilizando metodologóás de diseño. Desde esa perspectiva, podemos establecer que claramente hay un movimiento, que la gente en
todo el mundo ha estado sintonizándose con esta realidad - oportunidad - responsabiliddad. Es verdaderamente un tema critico de comprender
La primera vez que hablamos de Massive Change, La primera vez que hablamosos de Massive Channe
muchas personas me acusaron de megalómano, de querer controlar el mundo, porque mucho del diseño contemporáneo es sobre el contro not a formal problem. Because a social problem Sisyphus; I don't feel like I am not making any progress, that I am endlessly repeating a gesture, my own picture

A subjacent pattern in the whole ofyour work is to nderstand tratitional politics as one of many projectfor the Design of the World out of the res yos of the main meta-narratives of the $22^{\text {th }}$ Century. However, given the consistency of your work, there seems to be a binder, a structure original and invisible (conceptual, operative, mystical or motionall that supports your actions. Do you celleven some present form of meta-narrat actions and in the same movement defines what is absurd? Do you believe that a new narrative semerging? Do you feel a part of this new Great Narrative or do you believe that meta-narratives are exiting the social stageforever?

rby meta-narrative we mean a global

ore is sont would say yes. I do believe that

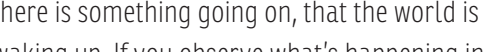
waking up. If you observe what's happening in such force in all regions of knowledge - many its subjects didn'te exist 20 years a ago - you will just didn't exist some time ago. movement. And it was like putting a pot of water on the stove... and when we went to getit a later there was a river in the pot. And it was
"ke "Wow! What is this thing?" And we tried Io map with our boats that new territory. We trie to name what we saw, and we called it 'desigg . . redesigned, reinvented using design methodology From that perspective, we clearly state that world are tuning in to this reality - opportunity The first time we talked about Massive Changes many people accused me of being a megaloman ice of wanting to control the world, because so much of contemporary design is about contron.
Massive Change is not. It's to assume responsibilly responsabbilidad por el mundo. Hay un movimiento por la responsababilidad que está despertando al hecho de que nuestro mundo es como es debido a
nosotros. Y Si l h hicimos de esta manera, también podemos hacerlo mejor. Podemos resolver los problemas que hemos creado. Si ses es una meta-

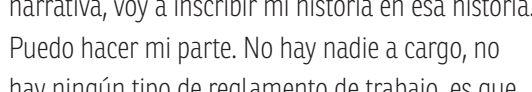
amente tenemos esta responsabilidad. Y una vez que despiertas a esa responsabilidad, .

Entonces, las nuevas meta-narrativas están compuestas por inquietudes, no por certezas sino por preguntasy acciones. Basados en lo anterior, yen queel diseño no es solamente una cosa, sino hecho, Massive Changerequiere del crecimiento constante). Provocativamente usted incluyede manera imperativa la necesidad de hacer pregun estupididas duranteel proceso ded diseño, una sugerencia que evoca la relevancia del idiota co actor polifico planteada por I sabelle Stengers (2005) iniciativa Massive Change, en el backendo on el preguntas stúpidas en inteligentes mediantesu

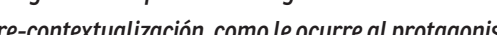
de la novela de Je Jerzy Kosinssi Desde eljardinin (19668)? ¿0, por el contrario, es saludable para el proyecto de diseño parecer un poco idiota ante la gente? ¿Cómo gestiona la presencia de este personaje idiotay sus preguntas estupidas? ¿Es vigorizante mantener al idiotota visible para bajar las barreras de Es Tundamential preservar el idiotata de principio a inin, participandoo activamente. Tengo que ser con mi inocencia porcue aprendo cosas, pero además porque necesito preservar esa capacida de hacer preguntas sencillas pero dificiles de contestar. Quiero poder decir «iqué pasa con esto? ¿Hemos pensado en esto otro?» Esa capacidad es muy valiosa para comenzar un proyecto, pero es Iguadmentite valiosa durantite su transcurso y hiasta el punto final del procesos, iusto antes de presionar
el botón y decir «prodúcant loy; antes de escribir el cheque. Hay veces que realmente necesitas hacer estas preguntas básicas e incómodas Es necesario desarrollar una culturar del proyecto que mas bers y otros. ¿En qué lugar coloca a li diota dentro de la entradade invitar a todos a interactuar librementey capaz de ejercer la i nocencia. Estoy comprometido realmente se puede lograr con la práctica. Y también

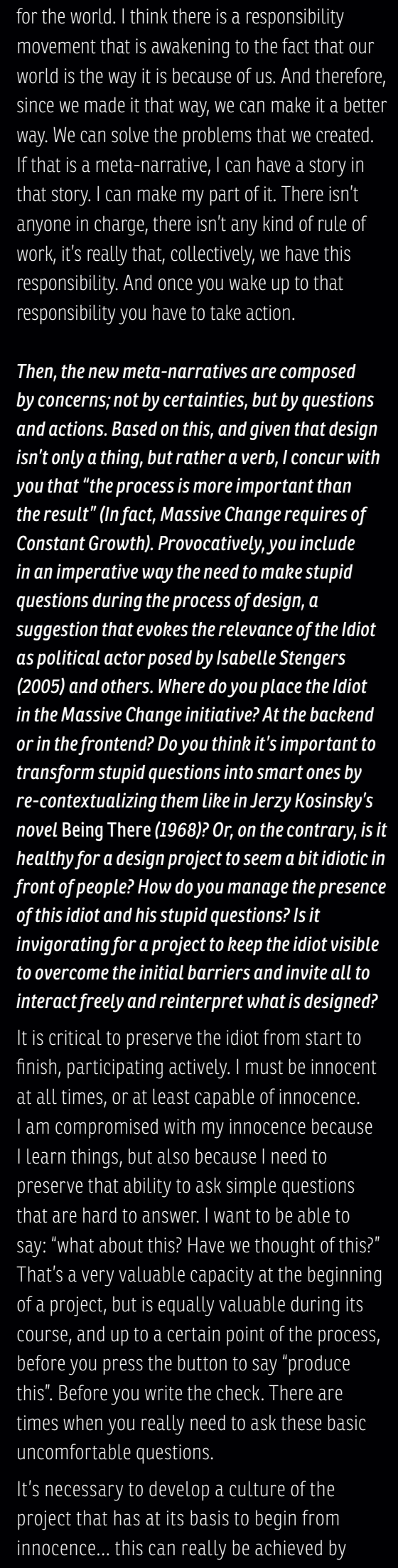

es mediante la práctica que podemos incorn
en las reuniones el pedir aloo incómodoy aprender a manejar el sentimiento que conlle es tan import n avergonzarse. Creo que esto que me viene a la mente con esto del idiof es que, a medida que el mundo se pone más
smart, nosotros nos volvemos relativamente Smarr, nosotros nos vovemos relativamente má
estúpidos. Esta es una sensación horrible, y creo que es uno de los

Cuando las personas ven el mundo pasar sin
poder alcanzarlo, se sienten excluidos sienten que el mundol les pasa por encima. Ven que las cosas literalmenteste se hacen más inteligentes que las computadorasa tienen cada ver más muchas de las cosas que antes hacían ellos. $S$,
las personas no entienden que ser el idiota está las personas no entienden que ser el idiotata está
bien, a medida que el mundo se hace más y más inteligente y sincronizado con las redes de ideass inteligentey y sncronizado con las reedes de i deass,
conocimimentos que pueden consumir a voluntad, Creo que es una fuente de populismo politico que en este momento invade todo el mundo. ¿ Has vis a un robot haciendo tu trabaji? Y $v e$ experimentée

vi un nuevo robot que hace el trabajo que y yice cuando era joven en una fábrica de plástico. por las noches.... un trabajaj terrible, erefectio

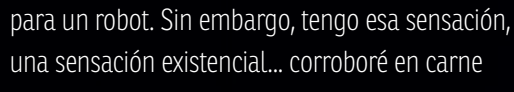

propia que esa experiencia tiene un impacto mut profundo. Es muy perturbador, a pesar de que ho me siento muy seguro en mi trabajio y es poco imaginas si trabajarars en una fábrica de plástica? ¿Como sentirías esta imagen? A medida que estos puestos de trabajio en
Norteamerica son reemplazados por tecnolich cibernética, corroboramos que en el mundo la solo se acelera. Va en una curva progresiva: no solo aumenta, está acelerando. Dado que esta tendencia irá en aumento, por la salud de nuess

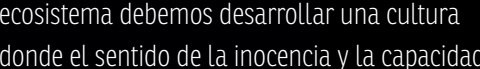
de hacer preguntas sencillas sean efectivamente considerados como algo realmente importante.

practice. And it is also through practice that we can asks something that is uncomfortable In a meeting, and learn to handle the feeling criatenging. One of the things I am thinking dertis that, as the world gets smarter, we gef and I think this is one of the greatest political challenges of our time.

When people see the world passing by, they over them. They see things literally getting smarter, they see that computers are more and more intelligent and can efficiently do many of the things they used to do before. If they don't understand that being the idiot is ok, as the world gets smarter and smarter and synchronized with networks of ideas and knowledge you can consume as you like, they will end up intensely angry and frustrated. I wher the world a the molical populism al over recently I went to a conference on robotics and I saw a new robot that does the job I did as a young man in a plastic factory. I had a jo at a plastic factory working nights when I was But I have this feeling, an existential feeling. I found out irist-nana that this experience hit a deep impact. It is deeply unnerving, even though I am very secure in my present wort anytime soon. But can you imagine if you worked in a plastic factory? How would you feel that image?

As the jobs in North America are replaced intelligence is only accelerating. It's on a progressive curve: it is not just going up, it is accelerating. And since this trend is going to only be exacerbated, for the health of or ecosystem, we need to develop a culture where the sense of innocence and the ability
to ask simple questions is actually considered is something really important.

Hay un movimiento por la responsabilidad que está despertando al hecho de que nuestro mundo es como es debido a nosotros. I think there is a responsibility movement that is awaking to the fact that our world is the way it is because of us.

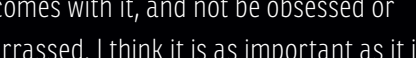
about in relation with this issue about the the presenge, we confirm that in the world 
Dado que esta tendencia irá en aumento, por la salud de nuestro ecosistema debemos desarrollar una cultura donde el sentido de la inocencia y la capacidad de hacer preguntas sencillas sean efectivamente considerados

\section{como algo realmente importante.}

And since this trend is going to only be exacerbated, for the health of our ecosystem, we need to develop a culture where the sense of innocence and the ability to ask simple questions is actually

considered as something really important.
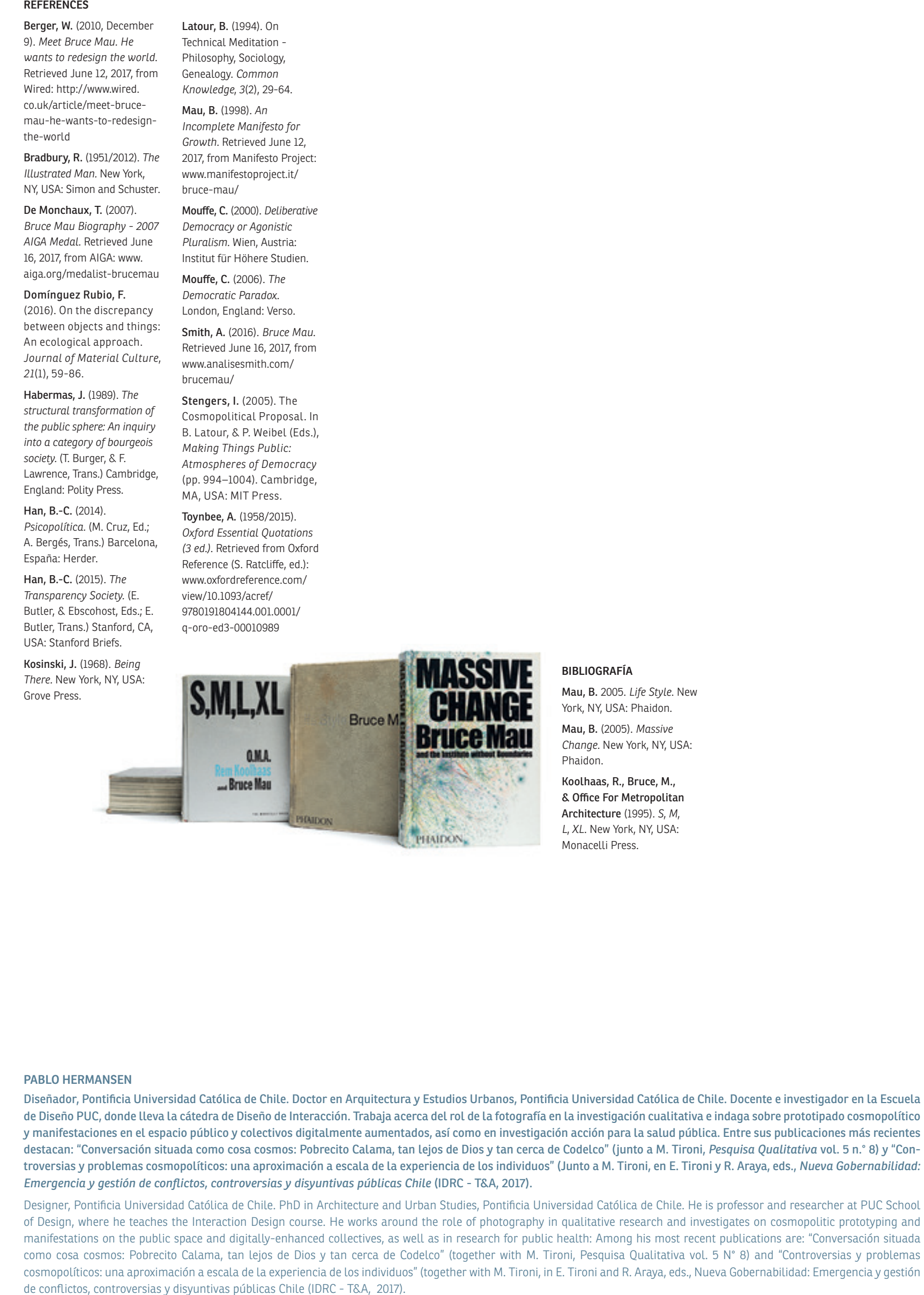

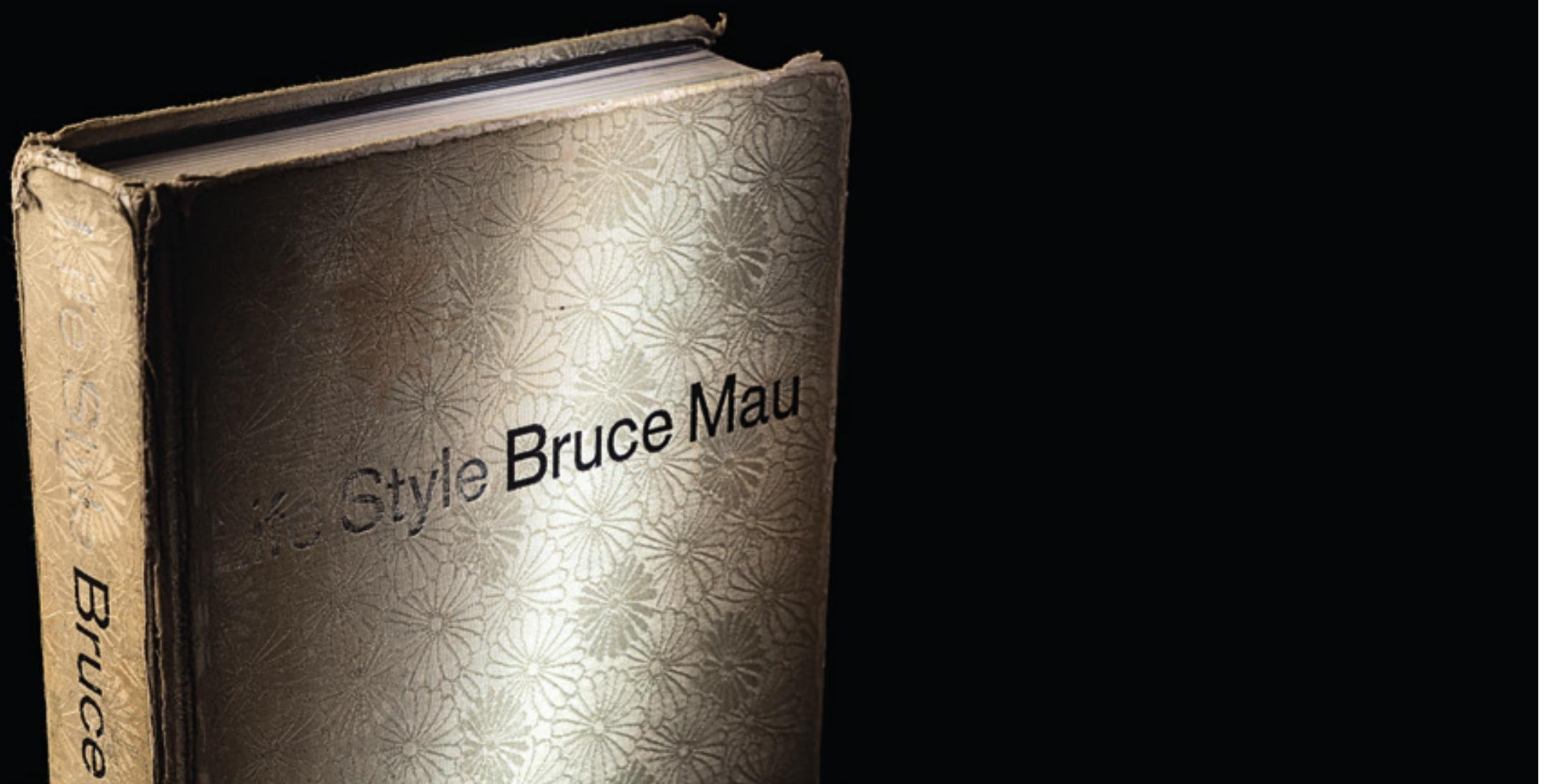

